\title{
Cold Pressor Test for Predicting Risk of Pregnancy Hypertension: A Case Control Study
}

\author{
$1^{\text {st }}$ Linda Yanti \\ Midwifery Program Faculty of Health \\ Harapan Bangsa University \\ Central Java, Indonesia \\ lindayanti@uhb.ac.id
}

\author{
$2^{\text {nd }}$ Mariah Ulfah \\ Nusing Departement Faculty of Health \\ Harapan Bangsa University \\ Central Java, Indonesia \\ maydaanzili@gmail.com
}

\begin{abstract}
As $60 \%$ of maternal deaths occurred during childbirth, $26.32 \%$ occurred during pregnancy and $13.68 \%$ occurred at the time of delivery. The causes of maternal mortality include metabolic disorders was $0.87 \%$, infections of $4.34 \%$, circulatory system disorders, $12.36 \%$, bleeding $\mathbf{3 0 . 3 7 \%}$, hypertension in pregnancy 32, 97\% and others 19, 09\%. Cold Pressor Test is one of the tests that can be used to screen for the tendency of hypertension. The purpose of this study is to explore the risk of hypertension in pregnancy by administering a cold pressor test (CPT). This research is a case-control study or analytic survey with a retrospective approach. This research was conducted at Kembaran Puskesmas 1 (Commubity Health Center) with a population of all pregnant women and the sample size in this study was calculated using the case-
\end{abstract}

\section{INTRODUCTION}

The results of Riskesdas (Basic Health Research) 2013 showed the prevalence of hypertension nationally $(25.8 \%)$, when compared with the results of riskesdas in 2007 (31.7/ 1000) showed a decrease in the prevalence rate, but this still needs to be aware of hypertension is one of the risks factors degenerative diseases between heart disease, stroke and other vascular diseases. Based on these data from $25.8 \%$ of people who have hypertension, only $1 / 3$ were diagnosed, the remaining $2 / 3$ are undiagnosed. Data shows that only $0.7 \%$ of people diagnosed with high blood pressure take hypertension medication. This shows that most people with hypertension cannot experience hypertension or receive treatment.[1]

Hypertension that does not get good treatment causes complications such as stroke, coronary heart disease, diabetes, kidney failure, and blindness. Stroke (51\%) and Coronary Heart Disease (45\%) were the highest causes of death. Target organ damage due to complications of hypertension will depend on the magnitude of the increase in blood pressure and the duration of the condition of the blood pressure that is undiagnosed and untreated. The control research design formula and obtained a sample of 40 for the case group and $\mathbf{4 0}$ respondents for the control group. Data were analyzed by using Pearson ChiSquare. The result showed that most pregnant women undergoing cold pressor tests are categorized as type reactors or have a risk of developing pregnancy hypertension. Meanwhile, the results of screening in pregnant women whose cold pressor test showed hyperactivity, had 23,619 times the risk of pregnancy hypertension. The conclusion was that CPT examination can be used as a reference to predict hypertension in pregnancy.

Keywords: cold pressor test (CPT), hyperreactive, hyporeactive, hypertension in pregnancy

organs of the body that are targeted include the brain, eyes, heart, kidneys, and can also affect the peripheral arteries themselves.

Based on SKDI data for 2017, in Banyumas, there is a Maternal Mortality Rate of 14 per 100,000 KH. $60 \%$ of maternal deaths occurred during childbirth, $26.32 \%$ occurred during pregnancy and $13.68 \%$ occurred at the time of delivery. The causes of maternal mortality include metabolic disorders as much as $0.87 \%$, infections $4.34 \%$, circulatory system disorders $12.36 \%$, bleeding $30.37 \%$, hypertension in pregnancy $32,97 \%$ and others as many as 19, 09\%.[2]

Hypertension is diagnosed if the blood pressure is $140 / 90 \mathrm{mmHg}$ or more on examination in two separate times at least 6 hours apart. Causes include genetic, environmental, hyperactivity of the sympathetic nervous system, renin-angiotensin system, defect in $\mathrm{Na}$ excretion, increased $\mathrm{Na}$, and intracellular $\mathrm{Ca}$ and factors that increase risk such as obesity, alcohol, smoking, and polycythemia. Preeclampsia is pregnancy-induced hypertension accompanied by a significant increase in proteinuria. In pregnancy, protein excretion can be increased but total protein up to $300 \mathrm{mg}$ per 24 hours is normal. 
systolic pressure rises greater than $20 \mathrm{~mm} / \mathrm{hg}$ and diastolic pressure is more than $15 \mathrm{~mm} / \mathrm{hg}$ from basal pressure, it is included in the hyperreactive group that has the potential for hypertension in the future, if the increase in blood pressure is less than that number then it is classified as a hyporeactive which is an increase in which is still considered normal and the possibility for future hypertension is small. The purpose of this study was to determine the risk of hypertension in pregnancy by administering a cold pressor test (CPT).[6]

\section{METHODS}

This is a case-control study or analytic survey with a retrospective approach.[7] This research was conducted at the Kembaran 1 Public Health Center. The population in this study were all pregnant women and the sample size in this study was calculated using the case control research design formula and obtained 40 samples for the case group and 40 respondents for the control group with inclusion criteria were pregnant women I, II, III, IV with a maximum age of 40 years. Univariate analysis in this study was to analyze blood pressure before and after the administration of cold pressor test intervention. Bivariate analysis was used to analyze the relationship between two variables. Bivariate analysis was performed to predict hypertension in pregnancy using Pearson Chi-Square.

cold pressor test (CPT) and also do regular checks to health workers.

Cold Pressor Test is one of the examinations that can be used to filter tests for the tendency of hypertension. Cold Pressor Test (CPT) is a heart load test by soaking one hand in ice water for two minutes without being lifted to see an increase in acute blood pressure as resistance to ejection from the left ventricle in the systemic arterial system which results in an acute increase in afterload.[4]

Increased blood pressure during CPT can be caused by several factors, including increased sympathetic nervous system activity, vasoconstriction, and feelings of pain during immersion in ice water. Blood pressure is influenced by two factors, namely blood flow, and peripheral vascular pressure. The body's blood flow is affected by cardiac output, heart rate, and blood volume itself. Cold stimulation of the hands dipped in ice water creates a stimulus to the heart's sympathetic nerves which causes vasocontraction of blood vessels. Vasocontraction of blood vessels causes increased blood pressure values.[5]

Besides this, pain during immersion in ice water also affects the rise in blood pressure in CPT. Pain causes stimulation of the autonomic nervous system which can increase heart rate. In theory, systole blood pressure and diastole increase when the hands are put into ice water, this is following the mechanism of the human body, ie when the body is in a relatively low-temperature condition the blood vessels will constrict (vasocontraction). When cooling
RESULTS AND DISCUSSION

Cold Pressor Test To Predict the Risk of Pregnancy Hypertension: Case Control Study

Table .1 Cold Pressor Test To Predict the Risk of Pregnancy

Hypertension: Case Control Study in Kembaran 1 Public Health $(\mathrm{n}=80)$

\begin{tabular}{|c|c|c|c|c|c|}
\hline & & \multicolumn{2}{|c|}{ Hypertension } & \multirow[t]{2}{*}{ p-value } & \multirow[t]{2}{*}{ OR } \\
\hline & & No & Yes & & \\
\hline \multirow{2}{*}{$\begin{array}{l}\text { Cold Pressor } \\
\text { Test Results }\end{array}$} & Hyporeaktor & 32 & 3 & \multirow[t]{2}{*}{0.000} & \multirow[t]{2}{*}{23.619} \\
\hline & Hypereaktor & 14 & 31 & & \\
\hline
\end{tabular}

Based on table 1, it shows that most pregnant women undergoing cold pressor test are categorized as hyperactive with a p-value $<0.00$ which means they are at risk of developing pregnancy hypertension. Meanwhile, the results of screening in pregnant women whose cold pressor test examination showed hyperactive, 23,619 times the risk of pregnancy hypertension.

Cold Pressor test is done by measuring the blood pressure response to cold stimuli given during the experiment. This test is used to detect hypertension early. Hyperreaction response during CPT can predict the risk of hypertension in the future.[8]

When afferent sensory nerve cold test is carried out it triggers systemic sympathetic activation which causes 
marked vasoconstriction. The result is an increased pulse pressure (normal is $40 \mathrm{mmHg}$ ), due to the release of catecholamines. This increased pressure fills the ventricles to a higher level, but the stroke volume decreases due to increased afterload. An increase in blood pressure during the cold pressor test can be caused by several factors, including an increase in sympathetic nervous system activity, vasoconstriction, and a feeling of pain during soaking in ice water with a temperature of $1-18^{\circ} \mathrm{c}$. Blood pressure is influenced by two factors, namely blood flow, and peripheral vascular pressure. the body's blood flow is affected by cardiac output, heart rate, and blood volume itself. Cold stimulation of the hands dipped in ice water creates a stimulus to the heart's sympathetic nerves which causes vasocontraction of blood vessels. Vasocontraction of blood vessels causes increased blood pressure values.

Besides this, pain during immersion in ice water also affects the increase in blood pressure in the cold pressor test. Pain causes stimulation of the autonomic nervous system which can increase heart rate. In theory, systole blood pressure and diastole increase when the hands are put into ice water, this is following the mechanism of the human body. when the body is in a relatively lowtemperature condition the blood vessels will constrict (vasocontraction). If the cooling systolic pressure rises greater than $20 \mathrm{~mm} / \mathrm{g}$ and the diastolic pressure is more than $15 \mathrm{~mm} / \mathrm{Hg}$ from the basal pressure, it belongs to the hyperreactive group that has the potential for hypertension in the future, but this effect usually returns to normal levels in a very period. short ( 5 minutes) after the withdrawal of the stressor. In this study, pregnant women who showed their cold pressor test results were hyperreact, 23,619 times the risk of pregnancy hypertension.[6]

Similarly, the study of Scheiner et al. Showed the high activity of the sympathetic nervous system, decreased adaptation, and delayed recovery of BP after stress or pressure applied to respondents with $\mathrm{RGH}(+)$ normotension. Research on the response of arteries to cold pressor tests in prehypertensive patients found that cold pressor tests can reduce the development of carotid and brachial arteries. Besides, cold pressor tests can reduce the strength of the pulse pressure in prehypertension. Afferent sensory nerves trigger systemic sympathetic activation which causes marked vasoconstriction. The result is an increased pulse pressure (normal is $40 \mathrm{mmHg}$ ), due to the release of catecholamines. This increased pressure fills the ventricles to a higher level, but the stroke volume decreases due to increased afterload.[9]

Pathology in pregnancy one of which is hypertension in pregnancy.[10] Hypertension is a condition where systolic blood pressure is more than $120 \mathrm{mmHg}$ and diastolic pressure is more than $80 \mathrm{mmHg}$.[11]
According to Prasetyo, the incidence of hypertension in pregnancy can be influenced by several factors (multiple causations). Maternal age ( $<20$ or $\geq 35$ years), primigravida, nulliparity and increased body mass index (BMI) are predisposing factors for hypertension in pregnancy.[12] The incidence of hypertension in pregnancy is the most dominant in the relationship between indirect factors with the incidence of physical risk 4-T pregnancy (too old, too young, too much and too close) is the variable of residence (village/city), level of education, economic status, and desire pregnant. Mothers who live in rural areas have a 1.1 times risk of $4 \mathrm{~T}$ pregnancy, while mothers with low education have 1.4 times the chance to experience pregnancy risk. Mothers from poor families have 1.3 times the risk of pregnancy, while mothers who have difficulty accessing health services are 1.9 times at risk of pregnancy with a 4-T condition, and mothers who don't/ don't want to get pregnant have 4.9 times the risk of pregnancy. Problems with the risk of pregnancy are more likely to occur in the group of mothers who live in rural areas, with low levels of education and economy, and difficulty accessing health facilities and do not or do not want a pregnancy.[13]

The risk of hypertension associated with hypertensive disorders of pregnancy is high blood pressure that occurs after pregnancy and lasts for more than 20 years. Until now $1 / 3$ of women with hypertensive pregnancy disorders can survive hypertension within a decade of pregnancy, this suggests that prevention of cardiovascular disease in these women should include monitoring blood pressure that starts immediately before pregnancy and after pregnancy.[14]

For pregnant women who are detected to be at risk of developing hypertension in pregnancy, they must be aware of conditions that complicate $6-8 \%$ of pregnancy which can significantly cause morbidity and fetal death. The strategy for the treatment of hypertension in pregnancy is to prevent cerebrovascular and maternal heart complications while maintaining uteroplacental blood flow and limiting drug toxicity to the fetus. The definitive treatment for acute hypertensive pregnancy syndrome is childbirth, although antihypertensive drugs are often needed to reduce maternal blood pressure to prevent maternal complications and reduce premature neonatal complications by allowing pregnancy to continue. Women with chronic hypertension should have a prenatal visit that includes an evaluation for secondary causes of hypertension, medication adjustments, and counseling regarding a high risk of preeclampsia.[15]

Weaknesses in this study include the discussion was not in details because due to lack of references to cold pressor tests in pregnant women. The research mostly done on people who had risk factors such as active smokers and people who had a family history of hypertension. 
enhanced reactivity, blunted adaptation, and delayed recovery," J. Hum. Hypertens., vol. 17, no. 12, pp. 829-840, 2003.

[10] Husin Farid, Asuhan Kebidanan Berbasis Bukti.

Bandung: Sagung Seto, 2013.

[11] Muttaqin A, Asuhan Keperawatan Klien Dengan Gangguan Sistem Kardiovaskular. Jakarta: Salemba

This research had strengths and limitations. This research took experimental action and cares given to pregnant women. While to limit this research lied in the research method and the number of samples should be added.

\section{CONCLUSION}

The conclusion of this research is cold pressor test examination can be used as a reference to predict hypertension in pregnancy

\section{ACKNOWLEDGMENTS}

The achievement of this research activity is inseparable from the assistance provided by the Harapan Bangsa Research and Community Service Institute that provides funding for the implementation of activities and the Kembaran 1 Community Health Center which has permitted to carry out this research.

\section{REFERENCES}

[1] Kemenkes.RI, "Infodatin Hipertensi," Infodatin, no. Hipertensi, pp. 1-7, 2014.

[2] BKKBN, Sdki 2017. 2017.

[3] F. G. Cunningham et al., Universal Free E-Book Store Universal Free E-Book Store. 2014.

[4] S. Hada, S. Amatya, and R. K. Shrestha, "Cold pressor test in borderline hypertensive university students," Kathmandu Univ. Med. J., vol. 14, no. 56, pp. 337-341, 2016.

[5] D. U. Silverthorn and J. Michael, "Cold stress and the cold pressor test," Adv. Physiol. Educ., vol. 37, no. 1, pp. 93-96, 2013.

[6] D. Wood, S. Shep, L. Elveback, and A. Schirger, "Cold pressor test as a predictor of hypertension," $J$. Tehran Univ. Hear. Cent., vol. 6, pp. 301-306, 1984.

[7] Notoatmodjo Soekidjo, Metodologi Penelitian Kesehatan. Jakarta: Salemba Medika, 2010.

[8] P. D. Dilipkumar, N. Dikshit, and D. Parchwani, "Blood Pressure Responsiveness to the Cold Pressor Test in Normotensive Young Adults," vol. 6, pp. 3542, 2017.

[9] G. M. Schneider, D. W. Jacobs, R. N. Gevirtz, and D. T. O"Connor, "Cardiovascular haemodynamic response to repeated mental stress in normotensive subjects at genetic risk of hypertension: Evidence of
Medika, 2012.

[12] Prasetyo R, "Kadar Vitamin A Pada Kehamilan Trimester II Sebagai Prediktor Preekslampsia," Diponegoro Univ. | Institutional Repos., 2011. [13]

P. S. H, D. Hapsari, I. Dharmayanti, and N.

Kusumawardani, "Faktor-Faktor Yang Berpengaruh Terhadap Risiko Kehamilan „4 Terlalu (4-T) Wanita Usia 10-59 Tahun (Analisis Riskesdas 2010)," Media Penelit. dan Pengemb. Kesehat., vol. 24, no. 3, pp. 143-152, 2015.

[14] I. Behrens et al., "Risk of post-pregnancy hypertension in women with a history of hypertensive disorders of pregnancy: Nationwide cohort study," BMJ, vol. 358, 2017.

[15] A. G. Kattah and V. D. Garovic, "The Management of Hypertension in Pregnancy," Adv. Chronic Kidney Dis., vol. 20, no. 3, pp. 229-239, 2013. 